\title{
Rights and Obligations of Human Rights in Islam Perspective
}

\author{
Zainal Arifin Hoesein ${ }^{1}$ \\ \{zainal_arifin@uia.ac.id/ Arifinhoesein55@yahoo.com ${ }^{1}$ \} \\ Professor of Law Faculty, Universitas Muhammadiyah Jakarta, Indonesia ${ }^{1}$
}

\begin{abstract}
The discourse of human rights in Islam is earlier than other concepts or teachings. That is, Islam comes inherently with the teachings of human rights. Islamic teachings of human rights can be found in the main source of normative teachings, namely Al-Qur'an and Hadith which contains the life practice of Muslims. This is evidenced by the Medina Charter (mitsaq al-Madinah) initiated by the Prophet Muhammad when migrated to the city of Medina. The covenant document contains, among other things, the recognition and affirmation that all groups in the city of the Prophet, whether Jews, Christians or Muslims, are one nation (ummatan wahidah). Islam in addition for talking about human rights also talks about the obligations of Human Rights (KAM) which becomes a counterweight and alignment to achieve the benefit of the ummah (maslahah al-ummah).
\end{abstract}

Keywords: Human Right, Human Liability, Islam.

\section{Introduction}

Human rights in Islam are transcendent for the benefit of humanity through Islamic shari'a which is revealed through revelation. According to the Shari'ah, human is a free being who has duties and responsibilities, and therefore they also have the right and freedom. The basis is that justice is established on the basis of equality (egalitarian, indiscriminate). That is, the task that is carried out will not be realized without the freedom, while the existential freedom does not materialize without the responsibility itself. ${ }^{1}$ In principle, Islam provides assurance of freedom to humans in order to avoid the futility and pressure, whether related to the problem of religion, politics, and ideology. However, the granting of freedom to humans does not mean they can use it absolutely, but in that freedom is contained rights and interests of others who must be respected as well.

At the beginning of the opening of the Medina Charter, it has been mentioned that all human beings are one people (ummatan wahidah), born from the same source, so there is no difference between one with another in all things. But in Islam there is one thing that makes a person regarded higher in the eyes of Allah SWT., Namely the level of faith, so not seen from the color of skin, race, ethnics, country, and gender, but the level of one's faith that distinguishes it with others. Undeniably also, that in Islam all human are brothers and sisters hood, they are the discent of one father and one mother, namely Adam and Hawa. This is as pointed out in the Qur'an letter An-Nisa verse 1:

\footnotetext{
${ }^{1}$ M. Luqman Hakim, Deklarasi Islam Tentang HAM, Surabaya: Risalah Gusti, 1993, hlm. 12.
} 
"O all human, fear your Lord Who created you from one by one, and from him, God created his wife; and of them, God has multiplied many men and women. And fear Allah who by His name you ask one another, and (nurture) the relationship of silaturrahim. Allah always guards and keeps watch over you."

Islam is a religion of humanity, the principle of this humanity in Islam is its respect for the man more than any other creature, regardless of color, race, tribe, and caste. In the letter of Al-Hujurat verse 13 it is explained that Allah SWT. creating all the different and nonsmoking human beings is not to oppress each other, to insult each other, and to drop each other. But this distinction is directed solely for all people to know each other and complement each other's flaws and strengths. ${ }^{2}$ Simply stated, that the human rights referred to by the Medina Charter are the similarities between each individual human being in all aspects of social life, as well as human freedom of religion and respect-between religions. The main principle in the Medina Charter is freedom of religion and protecting equal rights and equality of obligations upon all individuals of all citizens.

In Indonesia, the Human Rights Obligation (KAM) is quite clear, it is stated in the Republic Indonesia Law no. 39 of 1999 article 69, paragraph 2, which reads: "Every one's human rights creates basic obligations and responsibilities to respect the human rights of others on a reciprocal basis and the duty of the Government to respect, protect, uphold and promote it." From the sound, which we can say that the outline is in the piece "every human rights person raises basic obligations and responsibilities", it is clear that every human rights points that every human being possesses, is necessary and should be accountable, and that can be done with the implementation Human Liability.

\section{Research Problem}

Based on the background mentioned above, there are three problems that become the subject of this research:

1. What is the concept and the nature of human rights in Islam?

2. What are the human rights principles in the Qur'an and the Universal Declaration of Human Rights?

3. What is the concept and nature of Obigation Right in Islam?

\section{Discussion}

\subsection{The Concept and the Nature of Human Rights in Islam}

In understanding the concept and the nature of human rights in Islam, the author first explains the basic understanding of human rights. The word Human Right in Arabic is known as Haqq al-Insani al-Asasi or also called Haqq al-Insani ad-Daruri, which consists of three words, namely; the word right (haqq) means: belonging, possessing, authority, power to do

2 "O mankind, We created you from a man and a woman and made you nation and tribe to know one another. Verily the most honorable among you by Allah is the most wicked among you. Allah is Knower, Knower." 
something, and is something to be gained. The word man (al-insan) means: a creature that is intelligible and serves as the subject of the law. While the word asasi (al-asasi) means: basic or basic.

In terminologis, Human Rights in the view of Islam is a right inherent in human self that is natural and fundamental as a trust and grace of Allah SWT which must be maintained, respected, and protected by any individual, society or country. Even Ibn Rushd further affirms that Human Rights in Islamic perception has provided the format of protection, security, and anticipation of the various human rights that are primary (daruriyyat) owned by every human being. The protection comes in the form of anticipation of things that will threaten the existence of soul, honor, descent, property, and reason, and religion. ${ }^{3}$

Human right is a gift of Allah SWT for all human beings obtained naturally from birth, therefore human rights in line with the nature of man himself. According to the Shari'ah, human is a free being who has duties and responsibilities, and therefore he/she also has the right and freedom. The basis is that justice is established on the basis of (egalitarian) equality, indiscriminately. That is, the task that is carried out will not be realized without the freedom, while the existential freedom does not materialize without the responsibility itself. ${ }^{4}$ Islam places humans as beings who have the glory and virtue, possess the highest dignity and dignity, as stated in the Qur'an:

"And indeed we have honored the sons and daughters, we transport them on land and sea, we give them sustenance of the good and we exhort them with perfect advantages over most of the creatures we have created. ${ }^{5 "}$

The Islamic human rights system contains the basic principles of equality, freedom and respect for humanity. ${ }^{6}$ Equality, meaning Islam sees all humans are equal and have the same position, the only advantage enjoyed by other humans is determined by the level of sobriety. This is similar to the word of Allah SWT. in the letter of al-Hujurat verse 13:

"O mankind, We created you from a man and a woman and made you nation and tribe to know one another. Verily the most honorable among you in the sight of Allah is the most wicked among you. Allah is Knower, Knower."

The freedom in Islamic teachings is an important element. Islam is present to provide assurance of freedom to humans in order to avoid the futility and pressure, whether related to the problem of religion, politics and ideology. However, the granting of freedom to human beings does not mean that they can exercise such freedom absolutely, but in that freedom is contained the rights and interests of others who must be respected as well. Regarding respect for fellow human beings, in Islam all national races have the same honor. The basis of the equation is actually a manifestation of the very human form of human dignity. Essentially the image of honor lies in the superiority of humanity, not on individual superiority and ethnic race. Honor is applied globally through absolute solidarity of equality. All are descendants of Adam, if Adam is created from the land and honored by Allah, then all his offspring also have the same honor without exception.

${ }^{3}$ Ahmad Sukri Aji, Hak dan Kewajiban Asasi Manusia Dalam Perspektif Islam, Journal UINJKT, SALAM: Jurnal Sosial dan Budaya Syar'i, Vol. 2, No. 2, 2015, hlm. 3. Lihat juga: Wahbah Al-Zuhaili, Al-Figh Al-Islam Wa Adillatuhu, Juz I, Syiria: Darul Fikri,1984, hlm. 18-19.

${ }^{4}$ M. Luqman Hakim, Deklarasi Islam tentang HAM, Surabaya: Risalah Gusti, 1993, hlm. 12.

${ }^{5}$ QS Al-Isra ayat: 70

6 Harun Nasution dan Bahtiar Effendi, Hak Asasi Manusia dalam Islam, Jakarta: Yayasan Obor Indonesia, 1987, hlm. 124. 
The principles of respect for human rights, such as those concerning justice, equality, freedom of religion and others without discrimination on the basis of race, color, sex and religion can be found mainly in the verses of Makiyah (which descended during the Meccan period), then in the journey of Islamic civilization, scholars and Muslim scholars to develop rational concepts both in legal matters (commonly called fiqih) or theology (which is often called kalam science), and there began to be seen a lot of differences in the perception of human rights among scholars and Islamic scholars and goes on until now, coupled with the onslaught of Islamic Revivalism ${ }^{7}$ in the last decade. The spirit of Islamic revivalism also touches on human rights. ${ }^{8}$

Islam sees humans as noble ${ }^{9}$, the glory is attributed to the worship of human for their Rabb. Individuals are required to be responsible moral beings, who will carry all the deeds of their deeds without the possibility of delegating them to other persons. ${ }^{10}$ Therefore, the value of a person is equal to the value of universal humanity, as the value of universal humanity is equal in value to the cosmic value of the whole universe. ${ }^{11}$ In Islam the basic rights of human as a gift given by Allah SWT. (theosentris) ${ }^{12}$ Whereas in Western thought, human rights are natural rights (al-huquq athabi'iyyah / natural right) flowing from the idea that absolute sovereignty belongs to human, no other sovereign side of human (anthrophocentris) ${ }^{13} .^{14}$

Islam as a universal and comprehensive religion that surrounds several concepts. The concept in question is aqidah, worship and muamalat each containing teachings of faith. Aqidah, worship and muamalat, in addition to containing the teachings of faith, also includes the dimensions of Islamic teachings are based on the provisions of shari'ah (figh). Furthermore, in Islam, according to Abu A'Ala Al-Mawdudi. ${ }^{15}$ There are two concwpts about right. First, human right or Huquq ql-insan ad daruriyyah, and the second is Allah right (huquq Allah). ${ }^{16}$ Both types of rights can not be separated. And this is what distinguishes between the concept of human rights according to Islam and human rights from a Western perspective.

\footnotetext{
${ }^{7}$ Revivalism comes from the word revival, Revivalism is a revival movement. In Christianity the revival is a return to the sacred texts of the Bible (back to bible). Revivalism is emerging as a response to secularism. The Islamic Revivalism is a movement of Islamic purification of heresy, khurafat, tahayyul and call back to the Qur'an and Hadith.

${ }^{8}$ Diyan Shintaweechai Hadiansyah, Hak Asasi Manusia Dalam Perspektif Islam, Saturday, 24thDecember 2011 dalam: http://diyanshintaweecaihadiansyah.blogspot.co.id/2011/12/hak-asasimanusia-dalam-perspektif.html

${ }^{9}$ Look Al-Quran surat Al-Isra ayat: 70.

${ }^{10}$ Look Al-Qur'an surat Al-Baqarah ayat: 48 meaning: "And guard yourselves from the Day of Judgment (the Day of Resurrection) that one can not defend anyone, even the slightest; and (so are) not received syafa'at and ransom from him, and neither will they be helped"

${ }^{11}$ Look Al-Qur'an surat Al-Maidah ayat: 32

${ }^{12}$ Theocentris adalah sebuah pemikiran dimana semua proses dalam kehidupan di muka bumi ini akan kembali kepada Tuhan.

${ }^{13}$ Antrophocentris adalah pandangan yg menempatkan manusia sebagai pusat dari alam semesta.

${ }^{14}$ Muhammad Daud Ali, Hukum Islam, Jakarta: PT. Raja Grafindo, Cet. Ke-18, 2012, hlm. 59-60.

15 Abul A'la Maududi (Urdu: سيد ابو الاعلى مودودى- pengejaan alternatif nama akhir Maududi, dan Mawdudi) (25 September 1903-22 September 1979), juga dikenal sebagai Mawlana (Maulana) atau Syeikh Sayyid Abul A'la Mawdudi, adalah jurnalis, teolog, dan filsuf politik Pakistan Sunni, dan mayor pemikir Islam Ortodoks abad ke-20. Dia juga merupakan figur politik di negaranya (Pakistan), di mana didirikan partai Islam Jamaat Al-Islami. Lihat juga: Biografi Abu A'Ala Al-Maududi http://ufukislam.blogspot.com/2009/12/abul-ala-al-maududi.html

${ }^{16}$ Diyan Shintaweechai Hadiansyah, Hak Asasi Manusia Dalam Perspektif Islam , Op.cit., hlm. 6.
} 
It is important to underline that the core of human rights is egalitarianism, democracy, equality before the law, and social, economic and cultural justice. Differences for example, in the view of Islam is the will of Allah SWT, therefore all efforts that force that all people are uniform (one religion, one nation, one color, one political view etc.) is denial of sunnatullah. In the Qur'an Allah affirms:

"And if thy Lord willed, surely the believers of all the earth shall be all. Do you then (forcefully) persuade men to be believers all? ${ }^{17 \text { ", }}$

The above verse emphasizes that the attempt to equalize all the differences of all humanity is an act of human rights violation. It also shows that with human differences it is encouraged to help each other and work together. Therefore, the respect for differences among human beings is a primordial attitude that grows organically since Islam is called to humanity. Other principles of upholding human dignity and prestige are Islamic criticism of injustice, social imbalances and discrimination. These values are also strived for by human rights. The Qur'an has expressed this criticism, such as economic injustice in the statement "wealth should not go round among the rich alone", ${ }^{18}$ Also the zakat rules contained in the letter At-Taubah verse $60^{19}$ reinforces how Islam cares for the oppressed people who need to be helped and improved in dignity and prestige. Abandoning the plight of the poor and displaced is a violation of religion and human rights.

While at the socio-political level, Al-Qur'an wants to strengthen the most basic family unit consisting of both parents, children and grandparents. The family unit is the basis of harmony where human dignity begins to be established, therefore Qur'an cares about this aspect. $^{20}$ Therefore, the improvement of human dignity can only be meaningful if it is related to the aspects of economic, social and political justice. The above Qur'anic principles have been arranged in such a way that human rights are not violated either in the individual, family, or community level. Either economically, socially, and politically.

The Qur'an and as-Sunnah as the main source of law in Islam give high rewards to human rights. The Qur'an as the first legal source for Muslims has laid the foundations of human rights and truth and justice. This can be seen in the provisions contained in the Qur'an, among others:

1. The Qur'an describes creation and creatures, and about equality in creation, for example in Surah Al-Hujarat verse 13:

"O mankind, We created you from a man and a woman and made you nation and tribe so that you may know one another. Verily the most honorable among you by Allah is the most pious among you. Allah is Knower, Knower. "

\footnotetext{
${ }^{17}$ Al-Quran, surat Yunus ayat: 99.

${ }^{18}$ Look: Surat Al-Hasyr ayat 7: What are the spoils (fai-i) that Allah gave to His Messenger (of possessions) derived from the inhabitants of the cities of Hence is for God, for apostles, relatives, orphans, the poor and the people who are on the way, that the treasure should not circulate among the Rich among you alone. what the Apostle gave you, So take it. leave what he forbids. and fear Allah. Verily, Allah is harsh in punishment.

19 "Indeed, the zakat is for the poor, the poor, the zakat boards, the Mu'allaf who is enticed into their hearts, to (liberate) the slave, the one who is indebted, for the way of Allah, and those who on the way, as an obligatory provision of God; And Allah is Knower, Mighty, Wise."

${ }^{20}$ Look surat Al-Baqarah ayat: 83, surat An-Nisa' ayat: 36, surat Al-An'am ayat: 161.
} 
2. In the Qur'an there is also a verse about life, the maintenance of life and the provision of means of life. In addition, the Qur'an also speaks of honor, for example in Surah AlMaidah verse 32:

"Therefore We decreed (a law) unto the Children of Israel, that whosoever kills a man, not because of that man (kill) another, or not for making mischief in the earth, it is as if he has killed all humanity. And whoever preserves the life of a man, it is as if he has preserved all human life. And indeed indeed have come unto them Our apostles with (bring) clear explanations, and many of them afterwards have indeed exceeded the limits of corruption on the earth. "

3. The Qur'an has posed a stance against the oppression and the people who do zhalim and ordered to do justice which is expressed in the words: 'adl, qisth and qishash.

4. The Qur'an also speaks of the prohibition of force to guarantee freedom of thought, conscience and expressing aspirations, for example as proposed by Surah Al-Kahf verse 29:

"And say:" The truth is coming from your Lord, then whoever wants to believe, and whoever wants to (disbelieve) let him be infidel ". Lo! We have prepared for the tyrants the Fire, whose turmoil surrounds them. And if they ask for drink, they will be given to drink with water like a boiling iron that scorches the face. That's the worst drink and the ugliest resting place. "

Likewise with Sunnah Rasulullah SAW., He has provided guidance and examples in the enforcement and protection of human rights. This is for example seen in the command of Prophet SAW. which enjoins to preserve human rights and the rights of glory, even to persons of different faiths, through their sabd:

Remember whoever tries to disbelieve a mu'ahad (a heathen who has been protected by a peace treaty), degrading him, weighing him above his ability or taking something from him without his consent, then I am his rival on the Day of Resurrection. ${ }^{21}$

Other arrangements on human rights can also be seen in the Medina Charter ${ }^{22}$ and Khutbah Wada'. Both manuscripts pertaining to the Prophet (s). this then became the masterpiece of human rights in Islam. The khutbah wada 'is now known as the sermon of the Prophet SAW. with Muslims all over the world and affirmation of the perfection of Islamic teachings that he has conveyed. In fact, more than that, in the sermon that coincides with the implementation of wukuf in Arafat on 9 Dzhulhijjah $11 \mathrm{H}$, there is another thing that is very important for human life on earth, namely the commitment of Islam that has upheld the values of human rights. Where was the Prophet SAW. calling for: ${ }^{23}$

${ }^{21}$ Hadits from Abu Daud, dishahihkan by Syeikh Al-Albani on Shahih Al-Jami'.

${ }^{22}$ About contract of Madinah detail will explain in sub theme 3 and 4 in this paper.

${ }^{23}$ Nurcholis Majid said that Khutbah Wada' have taken point of view detail and strong about human right. Start from basic human right, soul, property, and respectbility, even about issue crucial in kontemporer era like labour right, the honor of human. Look: Mohammad Monib dan Islah Bahrawi, Islam \& Hak Asasi Manusia Dalam Pandangan Nurcholish Madjid, Jakarta: Gramedia Pustaka Utama, 2011, hlm. 93. 
"My brothers! Your blood and all your possessions will be pure to you, until your time comes before God as the day and the holy month. And you go to God, all of you will be held accountable for all your deeds."

In the life of the nation and state, in this case Indonesia, there are basic human duties (basic), among others: (1) Everyone shall respect the human rights of others, morals, ethics, and the order of life of society, nation, (2) Everyone in the territory of the Republic of Indonesia shall comply with the laws and regulations, the unwritten law, and international law (on human rights that have been accepted by the state of Republic Indonesia), (3) In exercising their rights and freedoms, every person shall be subject to the restrictions set by law, (4) Every citizen shall participate in the defense of the state, (5) Everyone's basic rights and obligations shall have the obligation to respect the human rights of others mutually .

Thus, human rights based on an Islamic perspective essentially all return to the five principles of human rights known as the term "dharuriyyat al-khamsah" (the five most dominant human rights) that protect human life and at the same time be held accountable. The five principles are: keeping the religion (hifzh ad-din), keeping the soul (hifzh an-nafs), maintaining the mind (hifzh 'aql), maintaining offspring (hifz an-nasl), and maintaining property (hifz al-mal). ${ }^{24}$

\subsection{Human Rights Principles In the Qur'an and the Universal Declaration of Human Rights}

The Islamic Declaration on Human Rights was compiled at the Islamic Conference in Makkah in 1981. The Declaration consists of 23 Articles that accommodate two basic forces, namely faith in God and the establishment of the Islamic order. In the introduction of this declaration it is argued that human rights in Islam stem from a belief that Allah Almighty, and only God as the law and the source of all human rights. The advantage of this declaration is that the text contains clear and unique references to the totality of rules derived from the Qur'an and Sunnah and other laws drawn from both sources by methods deemed to be lawful Islam. $^{25}$

The Human Rights Principles contained in the Universal Declaration of Human Rights (DUHAM) have been described in various verses of the Qur'an. If the human rights principles contained in the Universal Declaration of Human Rights are compared with the human rights contained in the teachings of Islam, then in the Qur'an and as-Sunnah will be encountered, among others, the principles of human rights as follows:

1. Human Dignity (al-Karamah al-Insaniyah)

In the Qur'an it is mentioned that man has a high position or dignity. The dignity that humans possess is totally absent in other beings. That high dignity is essentially a fitrah that is not separated in human beings. It has been affirmed by Allah SWT. in Surat alIsra 'verses 33 and 70 and the letter of Al-Maidah verse 32. The Qur'anic principles which have placed man on a high and noble dignity in tune with the principles outlined

${ }^{24}$ Muhammad Said Ramadhan Al-Buthi, Dhawabith Al-Mashlahah Al-Syari'ah Al-Islamiyyah, Beirut: Muassasah ar-Risalah, Cet.II, 1977, hlm. 119. Lihat juga Muh. Darwis, Urgensi Maqashid Al-Syari'ah Dalam Ijtihad, Jurnal Al-Ahkam, STAIN Palopo, Volume IV, No. 2, Agustus 2014.

${ }^{25}$ Abdul Aziz Dahlan (et.al), Ensiklopedia Hukum Islam, jakarta: Ichtiar baru van Hoeve, 1996, hlm. 498. Lihat juga: Frans Sayogie, Hak Kebebasan Beragama dalam Islam Ditinjau dari Perspektif Perlindungan Negara dan Hak Asasi Manusia Universal, Op. Cit, hlm. 42. 
by the Universal Declaration of Human Rights, among other things contained in Articles 1 and $3 .^{26}$

\section{Equation (al-Musawah)}

Basically all human beings are equal, because all are servants of Allah Ta'ala. Only one criterion can make a person high in rank from the others, namely his piety. ${ }^{27}$ The principle of equality (al-mu'adalah) is in the Universal Declaration of Human Rights contained in chapters 6 and $7 .^{28}$

In the view of Islam, man is born in a state of fitrah ${ }^{29}$, without carrying the sin of inheritance, and free without bearing the burden as a slave or sin of others. The concept of fitrah and merdeka also gives the meaning of equality of degree for every human being born, because both are born in the state of fithrah and free earlier. Differences of race, ethnic, or class precisely to further realize the introduction, not the symbol of degradation position. ${ }^{30}$

3. Justice (al-'Adalah)

The word al-'adalah or al-'adl in Al-Qur'an according to Al-Baidhawi as quoted Suyuthi Pulungan, means "mid and equation". ${ }^{31}$ While Sayyid Qutub emphasizes on the basis of equality as the principle of humanity that is owned by everyone. Justice for him is inclusive, not exclusively for a particular group, even if for example the justice is a Muslim for non-Muslims. ${ }^{32}$ The command to uphold justice is clearly stated in several verses of the Qur'an, for example: Al-Maidah verse: 8, Al-An'am verse: 152 and AlHujurat verse: 9 . Those verses mean that upholding justice is the duty of every believer by faith in Allah SWT, as an act of witness to Him. The mandatory order is addressed to

${ }^{26}$ Article 1:All people were born free and have the same of satus and human right.They have intellect, lustrous andwish they can interact in brother/sisterhood. ( Semua orang dilahirkan merdeka dan mempunyai martabat dan hak-hak yang sama. Mereka dikaruniai akal dan hati nurani dan hendaknya bergaul satu sama lain dalam persaudaraan). Article 3: All people have the right of life, freedom, and safety as individu. (Setiap orang berhak atas kehidupan, kebebasan dan keselamatan sebagai individu).

${ }^{27}$ Look Q.S al-Hujurat ayat 13

${ }^{28}$ Article 6: Everyone has the right to recognition before the law as a private human wherever they are (Setiap orang berhak atas pengakuan di depan hukum sebagai manusia pribadi dimana saja ia berada). article7: Everyone is equal before the law and is entitled to the same legal protection without discrimination. All are entitled to equal protection against any form of discrimination against this Declaration, and against any instigation that leads to such discrimination. (Semua orang sama di depan hukum dan berhak atas perlindungan hukum yang sama tanpa diskriminasi. Semua berhak atas perlindungan yang sama terhadap setiap bentuk diskriminasi yang bertentangan dengan Deklarasi ini,dan terhadap segala hasutan yang mengarah pada diskriminasi semacam ini).

${ }^{29}$ Look Hadits Rasulullah SAW.: "Setiap anak dilahirkan dlm keadaan fitrah (Islam), maka kedua orang tuanyalah yg menjadikannya Yahudi, Nashrani atau Majusi." (Shahih Bukhori, Hadits No. 1296)

30 Lihat: A. Qodri Abdillah Azizi, Masyarakat Madani Antara Cita dan Fakta; Kajian Historis Normative, dalam Ismail SM dan Abdul Mukti (Editor) Pendidikan Islam Demokratisasi dan Masyarakat Madani, Yogyakarta: Pustaka pelajar, Cet. I, 2000, hlm. 103.

${ }^{31}$ Suyuthi Pulungan, Prinsip-Prinsip Pemerintahan dalam Piagam Madinah Ditinjau dari Pandangan Al-Qur'an, Op. Cit., hlm. 225.

${ }^{32}$ Sayyid Quthub, Al-'Adalah Al-Ijtima'iyyah fi Al-Islam, jilid V, Beirut: Dar al-kitab Al-'Arabi, 1981, hlm. 118. 
two things, namely the order of establishing the law or solving the problem fairly, and the commandment is fair to the person who establishes and resolves a problem. ${ }^{33}$ That is, anyone who is given authority or power to lead others must be functioned to uphold justice and must do justice, it is two elements that can not be separated in an effort to uphold justice. Even in the smallest social unit, family, justice should be upheld like a husband to his wives. ${ }^{34}$

\section{Freedom (al-Hurriyah)}

Freedom is one of the basic things of everyone's life and is the recognition of a person or group and the glory of the dignity of another's humanity. Freedom to make everyone or the group feel elevated its existence and appreciated the value of humanity in the midst of the pluralism of the ummah. ${ }^{35}$ Among the freedoms that people need. First, freedom from persecution and claiming rights. This freedom requires an upholding of social order and security in society, so that they avoid arbitrary and unlawful acts in absolute terms. In that connection the Qur'an states that Allah SWT. strongly opposed to abusive acts, real or hidden, and violates human rights for no good reason. ${ }^{36}$ Second, freedom from fear, the Qur'an strongly emphasizes the importance of providing protection and maintaining the safety of the self and the soul of every human being. The Quran strongly denounces the person who kills a person, whom he calls the act as if it were the same as killing the whole person. On the contrary, the Qur'an praises the person who keeps the life of a person, whom he calls the act as being the same as preserving the whole human life. ${ }^{37}$

Third, free speech or opinion. In the history of Islam can be found evidence that shows that the Prophet SAW. giving freedom to his companions to speak and express their opinions. This is evident in the deliberations or consultations he undertakes to discuss matters. He developed a culture of freedom of opinion or dissent among his companions. $^{38}$ The Qur'an commands people to dare to use their minds, especially to express their true opinions. Therefore, every human being is in accordance with his dignity and nature as a being who thinks has the right to express his opinion freely, as long as it is not contrary to Islamic principles and can be accounted for. The right to express opinion freely is stated in the General Declaration of Human Rights clause 19. ${ }^{39}$

${ }^{33}$ Suyuthi Pulungan, Prinsip-Prinsip Pemerintahan dalam Piagam Madinah Ditinjau dari Pandangan Al-Qur an, Op. Cit. hlm. 225 - 227.

${ }^{34}$ Lihat surat An-Nisa' ayat: 3: "And if you are afraid that you will not be able to do justice to the (orphans) rights of orphans (if you marry her), marry other women whom you love: two, three or four. Then if you are afraid that you will not be able to do justice, then marry only one, or the slaves you have. That is closer to non-persecution."

${ }^{35}$ Ibid., hlm. 156. Lihat juga makalah: Arief AM, Hak Asasi Manusia Dalam Perspektif Al-Qur'an, 2015, hlm. 9

${ }^{36}$ Look QS Al-A'raf ayat 33

${ }^{37}$ Look QS Al-Maidah ayat 32

${ }^{38}$ Suyuthi Pulungan, Prinsip-Prinsip Pemerintahan dalam Piagam Madinah Ditinjau dari Pandangan Al-Qur`an, Op. Cit., hlm. 162. Look paper: Arief AM, Hak Asasi Manusia Dalam Perspektif AlQur'an, 2015, hlm. 10

39 Article 19: Every person shall have the right to freedom of expression; in this case including the freedom to hold opinions without interruption, and to seek, receive, convey information, opinion in any way and without regard to limits. 
Fourth, freedom of religion. Humans have the right of personal freedom to have any belief or ideology. This freedom must be respected and protected by others. This freedom of religion we can see from the statement in the letter of Al-Kafirun verse 6: "for you your religion and for me my religion." This verse contains the connotation of freedom of religion, but there is another verse more assertive in the same thing, that is "no coercion in (embracing) religion. Verily the truth is manifest from error." ${ }^{40}$ Another verse states: "And if thy Lord will will surely have faith all men that are on the earth. Will ye then compel men to be all believers" 41

But the fact is Allah SWT not doing Allah will. Allah only gives guidance through Allah messenger and revelation, for then human is given the freedom to choose his desired religion as stated in the letter of Al-Kahf verse 29: "And say:" Truth comes from your Lord, then whoever wants (believer), and whoever wants to (disbelieve) let him be infidel ". Lo! We have prepared for the tyrants the Fire, whose turmoil surrounds them. And if they ask for drink, they will be given to drink with water like a boiling iron that scorches the face. That's the worst drink and the ugliest resting place. "

The verses are strong evidence that it does not justify anyone forcing others to embrace Islam. Everyone is given the right to freedom to choose the religion he wants. That is, Islam since 14 centuries ago has legalized the teloransi and freedom of religion and the Prophet has practiced it. This is in line with article 18 of the Universal Declaration of Human Rights, which reads: Everyone has the right to freedom of thought, conscience, and religion.

5. Peace (as-Salam)

In the Qur'an Allah Ta'ala commands the believers to create peace in their internal environment. It is set out in the letter of Al-Hujurat verse 9:

"And if there are two groups of those who believe it is a war you should reconcile between the two! But if one breaks a covenant against another, let that break the covenant you fight back until it returns to God's command. If he has receded, reconcile between the two according to justice, and be fair; Allah loves those who are just. "

In Verse 9 it is clear that if there are two classes of believers fighting to stop them from war, by counsel, or by threat, and or by legal sanction. However, if one group is reluctant to accept peace according to Islamic law and violate it as predestined by Allah SWT. about the events for their creatures, they can be fought so that they submit and obey God's law, and return to God's command, that is peace. ${ }^{42}$

Therefore, persons acting as interpreters should be fair and honest, without taking sides with anyone by taking a neutral position as an arbitrator, and not taking economic and political advantage from him. The above verse describes the realization of internal peace, there is also another verse that enjoins the believers to love to receive peace to create an external peace. As confirmed by Allah SWT. in Surah Al-Anfal verse 61:

"And if they incline toward peace, then lean unto him and put him to trust in God. He is the Hearer, the Knower."

\footnotetext{
${ }^{40}$ Look QS Al-Baqarah ayat: 256.

${ }^{41}$ QS Yunus ayat: 99.

42 Ahmad Mustafa Al-Maraghi, Tafsir Al-Maraghi. Jilid XXVI Bairut: D’ar Al-Fikr, 1974, hlm. 129-131. Lihat juga makalah: Arief AM, Hak Asasi Manusia Dalam Perspektif Al-Qur'an, 2015, hlm. 10
} 


\section{Right to Social Security (al-Haq fi Al-Dlaman Al-Ijtima'i)}

In the Qur'an there are many verses which guarantee the minimum level and quality of life for all people. These teachings, among others, are the lives of the poor should be considered by the community, especially by those who have. Surat az-zariyat verse 19 has affirmed:

"And in their possessions there is a right for the poor who ask and the poor who are not partakers."

Such social security shall be granted, at least to those mentioned in the Qur'an, those entitled to social security. As explained in Surah al-Tawbah verse 60 below:

"The zakat is for the poor, the poor, the managers of the zakat, the mu'allaf whom he is persuaded, to (liberate) the slaves, the debtors, for the way of Allah and for them yuang is on the way, as a required provision of Allah, and Allah is Knower, Wise. "

The verse commands Muslims to practice zakat to those who need it. The purpose of zakat, among others, is to reduce poverty and create social welfare for the community. This is in line with Article 22 of the Universal Declaration of Human Rights, which reads: Everyone as a member of society has the right to social security.

\section{Right to property (Al-Haq fi Al-Milkiyah)}

In Islamic law, the right to own for a person is highly respected. Likewise with the protection of the property of a person is the duty of the ruler. Therefore, anyone, not even a ruler, is permitted to deprive another's property, unless it is in the public interest and in a pre-determined manner. This is in accordance with article 17 of the Universal Declaration of Human Rights, which reads (1) everyone has the right to own property, either alone or with others; (2) no one's property may be seized arbitrarily.

In this declaration, among others, explained that: ${ }^{43}$

1) The ruler and the people are the same subject before the law.

2) Every individual and every person shall strive by all means available to combat violations and revocation of this right.

3) Everyone not only has rights, but also has the obligation to protest injustice.

4) Every Muslim has the right and obligation to refuse to obey any orders that are contrary to the law, whoever commands them.

\subsection{The Concept and the Essence of Human Rights in Islam}

The Human Rights Obligation (KAM) is something that every human must do as a living being. Human Rights Obligation is essentially a duty that is in every human being and has been owned since human was born. The fundamental obligations are direct orders from God. An example of Obligation is believing in God, ${ }^{44}$ do good, and always appreciate fellow beings

\footnotetext{
${ }^{43}$ Ibid.

${ }^{44}$ Look al-A'raf ayat 172: "And (remember), when your Lord took the offspring of the sons of Adam from their sobbi and God took witness of their souls (saying): "Am I not your Lord?" They replied: "True (You are our Lord), we are witnesses". (We do so) so that on the Day of Resurrection you will not say: "We (the people of Adam) are the guilty of this (the unity of God)"'"
} 
in this world. Another example of the simplest of Oblugation Rights is to respect others so that the right of others to honor is fulfilled.

The term "Human Rights Obligations" is not so well known, when compared to the term of Human Rights which is always commemorated and celebrated every year. But not so with basic obligations, often forgotten people. Prof. Jimly Asshiddiqie in some of his papers stated that if we observe also use the term 'Human Liability'. However, in Law No. 39/1999 on Human Rights in Article 1 paragraph (2) uses another term to discuss this matter, namely 'Basic Obligations'. Perhaps some of us ask why the Human Rights Law does not use the term 'Human Rights Obligation', as when the Act speaks of 'Human Rights' and regulates an obligation under the Human Rights Chapter of the 1945 Constitution? The simple answer, in the Human Rights Law, the position of 'basic duty' is simply to ensure that human rights are done. So that human rights are absolute, then there will be exceptions, that is simple when offending the human rights of others, either individuals or groups.

The Indonesian Ulema Council (MUI) said about human rights at the MUNAS VI of 2000, establishing and recognizing international human rights in general as long as it is not against Islam. On the other hand, MUI also deplore the emphasis on human rights that are too biased on the rights and forget the obligations, and encourage the importance of balance and harmony between rights and obligations. ${ }^{45}$

Based on reality, Islamic law always gives rights and obligations in tandem (arm in arm). For example, the human being has the right to be guarded of his life, but there are also times when he is obliged to save his life in jihad qital or war (in this case not only prohibited to take the lives of others without rights). Humans are also entitled to earn sustenance (guaranteed), and obliged to share fortune to others. Man has the right to own the land, accompanied by the obligation to manage the land and so forth.

The balance between rights and obligations lies in the most basic essence of the concept of human and himself. Human was created for the purpose of worshiping Allah SWT. ${ }^{46}$ Even one of the wisdoms of the creation of the seven heavens and the earth is to remind man of God's power over everything that is closely related to the purpose of human creation. ${ }^{47}$ Thus, can be interpreted that true man actually created with a basic obligation attached to him. So with a position like this, the fate of the creation is very dependent on the mercy of the Creator, Allah SWT.

Obligation is actually a form of restrictions on human rights that can make the source of the emergence of the nature of individual egoism. Because human beings not only have human rights, they also have basic obligations. Usually, people only demand rights, but forget that they also have an obligation to respect the rights of others. Obligation is also something to be done by every human being as a living being.

In the life of religion and the state, there is a Human Rights Obligation to be fulfilled, another: (1) Human obligation to perform human duties, (2) moral obligation on the basis of right and wrong norms as accepted and acknowledged by society, (3) on the basis of social environmental norms and behavior, (4) Obligations to God the Creator.

Thus it can be understood that the nature of respect and protection of human rights in the concept of Islam is to maintain the existence of a whole human being and the balance, namely

45 Fatwa Musyawarah Nasional VI Majelis Ulama Indonesia Nomor: 6/Munas Vi/MUI/2000 Tentang Hak-Hak Asasi Manusia (HAM): http://muijatim.org/wp-content/uploads/2016/09/Hak-hak-AsasiManusia-HAM_2000.pdf

${ }^{46}$ Look QS Adz-Dzaariyat ayat 56.

${ }^{47}$ Look QS Ath-Thalaq ayat 12. 
the balance between rights and obligations, as well as the balance between individual and social interests. So that in fulfilling and demanding rights can not be separated from the fulfillment of obligations that must be implemented. So also in the interests of individuals should not damage the interests of the people. Therefore, the fulfillment, protection and respect for human rights must be accompanied by the fulfillment of Obligation human right in private life, community life, and state. ${ }^{48}$

\section{Conclusion}

From the above explanation, the authors conclude that are answering the formulation of the problem or subject matter that has been formulated in this study:

1. Human rights in the perspective of Islam is a set of rights attached to the nature and existence of human beings as creatures of God Almighty. As a gift that must be preserved and preserved.

2. The principles of human rights in the Qur'an and the Universal Declaration of Human Rights which have been described in various verses of the Qur'an comprise: The principle of human dignity (al-karamah al-insaniyah), the principle of equality (al-musawah), the principle of justice (al-'adalah), the principle of freedom (al-hurriyah), the principle of peace (as-salam), the principle of the right to social security (al-haq fi al-dlaman al-ijtima'i) and the principle of the right to property -haq fi al-milkiyah).

3. Human Rights Obligation is a set of obligations inherent in human nature and existence to respect, uphold, and protect human rights. So the essence of human rights is the integration of human rights and obligation that take place synergistically and in balance. All this is a blessing and a grace as well as a mandate that will be held accountable before the court of Allah SWT. Rabbul 'alamin.

\section{References}

\section{Book:}

[1]. Al-Quran dan Terjemahnya, Departemen Agama RI, Jakarta: PT. Syamil Cipta Media, Cetakan 2005.

[2]. Adh-Dahahham, Muhammad, Muhammad, Huquq al-Insan fi al-Islam wa Ri ayatihi li al-Qayyim wa al-Ma`ani al-Insaniyyah, Kairo: Syirkah al-Misriyyah, 1971.

[3]. Ali, Daud, Muhammad, Hukum Islam, Jakarta: PT. Raja Grafindo, Cet. Ke-18, 2012.

[4]. Al-Zuhaili, Wahbah, Al-Fiqh Al-Islam Wa Adillatuhu, Juz I, Syiria: Darul Fikri,1984.

[5]. Azizi, Abdillah, Qodri, Masyarakat Madani Antara Cita dan Fakta; Kajian Historis Normative, dalam Ismail SM dan Abdul Mukti (Editor) Pendidikan Islam Demokratisasi dan Masyarakat Madani, Yogyakarta: Pustaka pelajar, Cet. I, 2000.

[6]. Dahlan, Aziz, Abdul, (et.al), Ensiklopedia Hukum Islam, Jakarta: Ichtiar baru van Hoeve, 1996.

[7]. Darwis, Muh., Urgensi Maqashid Al-Syari'ah Dalam Ijtihad, Jurnal Al-Ahkam, STAIN Palopo, Volume IV, No. 2, Agustus 2014.

[8]. Hakim, M. Luqman, Deklarasi Islam Tentang HAM, Surabaya: Risalah Gusti, 1993.

\footnotetext{
${ }^{48}$ Muhammad Muhammad adh-Dahahham, Huquq al-Insan fi al-Islam wa Ri ayatihi li al-Qayyim wa alMa`ani al-Insaniyyah, Kairo: Syirkah al-Misriyyah, 1971, hlm.13. Lihat juga: Ahmad Sukri Aji, Hak dan Kewajiban Asasi Manusia Dalam Perspektif Islam, Op. Cit., hlm. 3.
} 
[9]. Monib, Mohammad dan Bahrawi, Islah, Islam \& Hak Asasi Manusia Dalam Pandangan Nurcholish Madjid, Jakarta: Gramedia Pustaka Utama, 2011.

[10].Muhammad Said Ramadhan Al-Buthi, Dhawabith Al-Mashlahah Al-Syari'ah Al-Islamiyyah, Beirut: Muassasah ar-Risalah, Cet.II, 1977.

[11].Mustafa Al-Maraghi, Ahmad, Tafsir Al-Maraghi. Jilid XXVI Bairut: D’ar Al-Fikr, 1974.

[12].Nasution, Harun dan Effendi, Bahtiar, Hak Asasi Manusia dalam Islam, Jakarta: Yayasan Obor Indonesia, 1987.

[13]. Sayogie, Frans, Hak Kebebasan Beragama dalam Islam Ditinjau dari Perspektif Perlindungan Negara dan Hak Asasi Manusia Universal, Fak. Hukum-Univ. Indonesia, 2012.

[14].Pulungan, J. Suyuthi, Prinsip-Prinsip Pemerintahan dalam Piagam Madinah Ditinjau dari Pandangan Al-Qur`an, Jakarta: Rajawali Press, 1996.

[15].Quthub, Sayyid, Al-'Adalah Al-Ijtima'iyyah fi Al-Islam, Jilid V, Beirut: Dar al-kitab Al-'Arabi, 1981.

\section{Paper/Journal/Internet}

[1]. Aji, Sukri, Ahmad, Hak dan Kewajiban Asasi Manusia Dalam Perspektif Islam, Journal UINJKT, SALAM: Jurnal Sosial dan Budaya Syar'i, Vol. 2, No. 2, 2015.

[2]. AM, Arief, Hak Asasi Manusia Dalam Perspektif Al-Qur'an, 2015:

[3]. http://abiavisha.blogspot.co.id/2015/06/hak-asasi-manusia-dalam-perspektif-al.html

[4]. Biografi Abu A'Ala Al-Maududi:http://ufukislam.blogspot.com/2009/12/abul-ala-al-maududi.html

[5]. Fatwa Musyawarah Nasional VI Majelis Ulama Indonesia Nomor: 6/Munas Vi/MUI/2000 Tentang Hak-Hak Asasi Manusia (HAM): http://muijatim.org/wp-content/uploads/2016/09/Hak-hak-AsasiManusia-HAM_2000.pdf

[6]. Hadiansyah, Shintaweechai, Diyan, Hak Asasi Manusia Dalam Perspektif Islam , Sabtu, 24Desember 2011 dalam: http://diyanshintaweecaihadiansyah.blogspot.co.id/2011/12/hak-asasimanusia-dalam-perspektif.html

[7]. Muhammad, Fatur, Implementasi Kewajiban Asasi Manusia Menurut UUD 1945 Dalam Masyarakat:https://www.kompasiana.com/fatoorr/5a49a74916835f4eb1556225/implementasikewajiban-asasi-manusia-menurut-uud-1945-dalam-masyarakat

[8]. Muhammadin, Matahati, Farji, Adakah Sebuah Kewajiban Asasi Manusia: http://www.republika.co.id/berita/kolom/wacana/18/01/25/p3437s291-adakah-sebuah-kewajibanasasi-manusia 